\title{
A new species of the genus Halticopterina Erdös, 1946 (Hymenoptera: Chalcidoidea: Pteromalidae) from Kazakhstan
}

\author{
Новый вид рода Halticopterina Erdös, 1946 (Hymenoptera: \\ Chalcidoidea: Pteromalidae) из Казахстана
}

\author{
K.A. Dzhanokmen \\ K.A. Ажанокмен
}

Institute of Zoology of the Republic of Kazakhstan, Akademgorodok, 93 Al-Farabi Ave., Almaty 050060, Kazakhstan. E-mail: dzhanokmen@yahoo.com

Институт зоологии Республики Казахстан, Академгородок, пр. Аль-Фараби 93, Алматы 050060, Казахстан.

KEY WORDS: Halticopterina, Pteromalidae, Chalcidoidea, Hymenoptera, Charyn State National Natural Park, Haloxylon aphyllum, Atraphaxis sp., Kazakhstan.

КЛЮЧЕВЫЕ СЛОВА: Halticopterina, Pteromalidae, Chalcidoidea, Hymenoptera, Чарынский государственный национальный природный парк, Haloxylon aphyllum, Atraphaxis sp., Казахстан.

ABSTRACT. Halticopterina rasnitsyni sp.n. from Kazakhstan is described. It was collected on Haloxylon aphyllum and Atraphaxis sp. in Charyn State National Natural Park. This species is characterized by transverse visible part of metasomal petiole with very fine sculpture and by very short, light and hardly conspicuous pilosity of forewings.

РЕЗЮМЕ. Halticopterina rasnitsyni sp.n. описывается из Казахстана. Вид был собран на саксауле (Haloxylon aphyllum) и курчавке (Atraphaxis sp.) в Чарынском государственном национальном природном парке. Новый вид характеризуется поперечной видимой частью метасомального стебелька с очень слабой скульптурой, а также очень коротким, светлым и едва заметным опушением передних крыльев.

\section{Introduction}

The genus Halticopterina Erdös, 1946 comprises three described species in the Palaearctic Region, namely: H. triannulata Erdös, 1946, H. moczari Erdös, 1954 (=H. penthocoryne Dzhanokmen, 1975) and H. lauta (Dzhanokmen, 1975) [Dzhanokmen, 1975; Dzhanokmen, Grissell, 2003]. All those species were found in Kazakhstan; however, the new species that is described below appeared to be very rare. It was collected for the first time only in 2009 on Haloxylon aphyllum (Minkw.) Iljin, 1934 (Chenopodiaceae) and on Atraphaxis sp. (Polygonaceae) in Charyn State National Natural Park.

Taxonomic part

Halticopterina rasnitsyni sp.n. Figs 1-3.

MATERIAL. Holotype: female, SE Kazakhstan, Almaty Prov., near Chundzha, Charyn State National Natural Park, valley of the
Charyn River in the vicinity of the ash-tree grove (cordon Dacha), on Haloxylon aphyllum (Minkw.) Iljin, 1.X.2009 (Dzhanokmen). Paratypes: SE Kazakhstan, Almaty Prov., near Chundzha, Charyn State National Natural Park, valley of the Charyn River in the vicinity of the ash-tree grove (cordon Dacha), on Haloxylon aphyllum: 2 females, 1.X.2009; 1 female, 5.X.2009; 1 female, 6.X.2009; 1 female, 1 male, 7.X.2009 (Dzhanokmen); 5 km S Chundzha, on Atraphaxis sp., 1 female, 29.IX.2010 (Dzhanokmen). Type material is deposited in the collection of the Institute of Zoology of the Republic of Kazakhstan.

DESCRIPTION. Female (holotype). Head about 2.4 times as broad as long, rather broader than high in front view. POL $=1.3$ OOL. Eyes short-oval. Major diameter of eye 1.3 times more its minor diameter and two times more than height of gena. Antenna inserted at or slightly below level of ventral edge of eyes. Antennal formula 11353 (Fig. 1). Scape not reaching median ocellus. Flagellum moderately clavate. Pedicellus nearly as long as anelli and first funicular segment combined. All anelli strongly transverse. First and second funicular segments square; funicular segments 3 to 5 transverse. Funicle with sensilla arranged in one row on each segment. Anterior margin of clypeus deeply incised medially; each mandible with four teeth (Fig. 2). Maxillary palpi 4-segmented; labial palpi 3-segmented.

Pronotum very short, much narrower than mesoscutum, with collar anteriorly rounded and posteriorly with narrow shining strip. Notauli incomplete. Mesoscutum finely reticulate. Scutellum 1.8 times as long as propodeum, strongly convex, with weak frenal furrow, more finely reticulate than mesoscutum. Median area of propodeum smooth and shiny, with median carina; propodeal nucha represented only by narrow smooth strip. Mesepimeron with smooth triangular area (mesepimeron superior) below base of hind wings. Fore wing: marginal vein 2.2 times as long as stigmal vein; postmarginal vein 1.6 times as long as stigmal vein (Fig. 3); upper surface of wing including basal cell with hairs, 


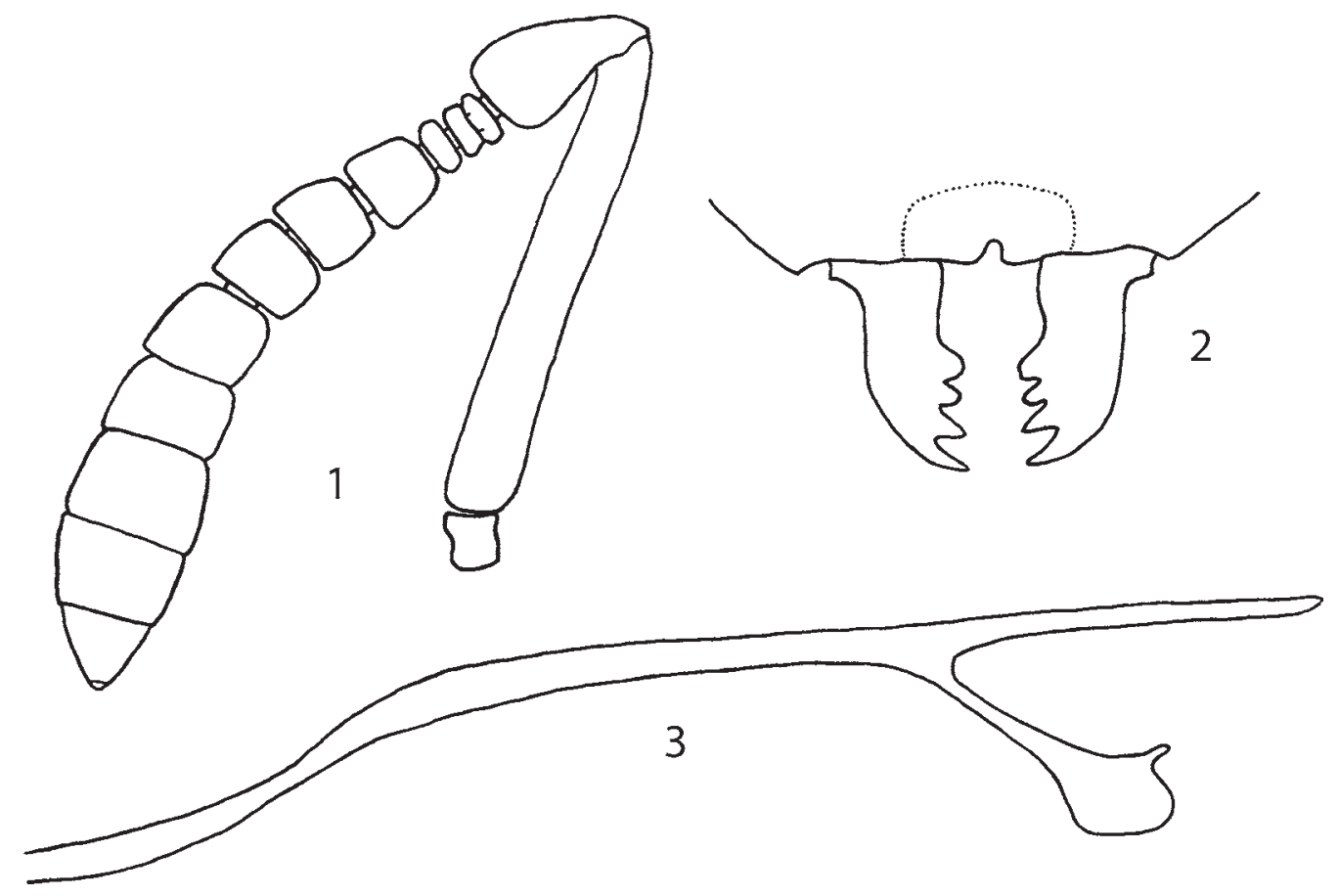

Figs 1-3. Female of Halticopterina rasnitsyni sp.n.: 1 - antenna, 2 - lower margin of clypeus and mandibles, 3 - venation of forewing.

Рис. 1-3. Самка Halticopterina rasnitsyni sp.n.: 1 - антенна, 2 - нижний край наличника и мандибулы, 3 - жилкование переднего крыла.

but pilosity extremely short, light and hardly conspicuous; veins more or less light. Apical margin of wing with very short fringe.

Metasoma short-oval, pointed apically, 1.5 times as long as broad. Visible part of metasomal petiole transverse, its sculpture very fine, nearly alutaceous.

Entire body brightly green, strongly metallic. Scape, flagellum, femora, tibiae and tarsi yellowish testaceous. Fore and mid coxae brownish, hind coxa of the same colour as body; wings hyaline with veins pale yellow. Length $2.0 \mathrm{~mm}$.

Male. Similar to female. Maxillary palpi modified, their subterminal and terminal segments moderately expanded apically; male stipites strongly enlarged, reaching level of foramen magnum. Antennae, maxillary palpi, femora, tibiae and tarsi pale yellow, fore and mid coxae mainly pale yellow, hind coxa mainly metallic. Length $1.4 \mathrm{~mm}$.

COMPARATIVE REMARKS. The new species differs from $H$. triannulata and $H$. moczari by having transverse visible part of metasomal petiole with very fine, nearly alutaceous sculpture, and extremely short, light and hardly conspicuous pilosity of fore wings.

ETYMOLOGY. The species is named after Alexandr Rasnitsyn, an eminent Russian scientist who has significantly contributed to the study of Hymenoptera.

ACKNOWLEDGEMENTS. I am very grateful to T.A. Bectemesov, Director of Charyn State National Natural Park, and M.N. Mansurova, Manager of the Department of Science and Tourism of the Natural Park) for providing facilities during the course of fieldwork.

\section{References}

Dzhanokmen K.A. 1975. [New palaearctic species of parasitic Hymenoptera of the family Pteromalidae (Hymenoptera, Chalcidoidea)] // Entomologicheskoe Obozrenie. Vol.54. No.3. P.625-635 [in Russian].

Dzhanokmen K.A., Grissell E.E. 2003. Nomenclatural changes in Pteromalidae, with a description of the first New World species of Ormocerus Walker (Hymenoptera: Chalcidoidea) // Proceedings of the Entomological Society of Washington. Vol.105. No.3. P.535-541. 